\title{
Abordagem biografemática ao drama homoerótico Greta Garbo quem diria, acabou no Irajá
}

\section{Biographematical approach to the homoerotic drama Greta Garbo quem diria, acabou no Irajá}

Tiago Calazans Simões ${ }^{1}$

https://orcid.org/0000-0003-2285-216X

André Luis Mitidieri Pereira ${ }^{2}$ https://orcid.org/0000-0001-5731-4770

Resumo: Buscamos visibilizar experiências de sujeitos dissidentes da sexualidade normativa e desejos interditados por discursos autoritários, valorizando temas e discussões que sempre ficaram às margens do cânone literário. O texto dramático analisado - Greta Garbo, quem diria, acabou no Irajá -, de Fernando Mello (1974), insere-se no contexto repressivo, e policiado pela censura, da ditadura hétero-militar brasileira nos anos 1970-1980. Para tal proposta, apostamos na noção de "escrita/literatura homoerótica" (SILVA, 2009), na crítica ao objeto literário proposto, correlacionando-o com os conceitos de "espaço biográfico" (ARFUCH, 2010); "biografema" (BARTHES, 1990) e sua releitura no universo da diversidade sexual e de gênero. Durante a análise, de cunho bibliográfico, constatamos que a censura tentou manipular e orientar o sentido da obra, de acordo com a sua visão: a doutrina pedagógica de segurança nacional, cuja busca foi por identificar e combater um "inimigo interno". Questionando as implicações dos cortes censórios, no texto escolhido, buscamos uma (re)leitura que ressignifique a experiência homoerótica da personagem Renato

\footnotetext{
${ }^{1}$ Mestrando no Programa de Pós-graduação em Letras: Linguagens e Representações (PPGLLR), na Universidade Estadual de Santa Cruz (UESC), Ilhéus-Bahia, Brasil. E-mail: tiagocalazanssimoes@gmail.com.

${ }^{2}$ Docente no curso de graduação em Letras, do Departamento de Letras e Artes, e no Programa de Pós-Graduação em Letras: Linguagens e Representações (PPGLLR), da Universidade Estadual de Santa Cruz (UESC), Ilhéus-Bahia, Brasil. Email: mitidierister@gmail.com
} 
Palavras-chave: Censura; homossexualidade; literatura; protagonista gay.

\begin{abstract}
We seek to show the experiences of dissident subjects of normative sexuality and desires interdicted by authoritarian discourses, valuing themes and discussions that have always remained on the margins of the literary canon. The dramatic text analyzed - Greta Garbo, quem diria, acabou no Irajá -, by Fernando Mello (1974), is inserted in the repressive context and policed by the censorship of the Brazilian hetero-military dictatorship in the years 1970-1980. For this proposal, we rely on the notion of "homoerotic writing / literature" (SILVA, 2009), in the review to the proposed literary object, correlating it with the concepts of "biographical space" (ARFUCH, 2010); "Biographeme" (Barthes, 1990) and its re-reading in the universe of sexual and gender diversity. During the analysis, we noticed that censorship tried to manipulate and guide the meaning of the dramaturgical text, according to its vision: the pedagogical doctrine of national security, which sought to identify and combat an "internal enemy." By questioning the implications of the censorship cuts, in the chosen text, we are looking for a (re) reading that resignify the homoerotic experience of the character Renato.
\end{abstract}

Keywords: Censorship; dramaturgy; homosexuality; Literature, gay central character.

[...] Abra a porta desse armário Que não tem censura pra me segurar Abra a porta desse armário Que alegria cura, venha me beijar [...

(Daniela Mercury; Caetano Veloso)

Na circunscrição de teorias e discussões acerca da biografia, bem como de gêneros e formas similares, destacamos primeiramente a potencialidade crítica e ampla das relações do eu (autoral) com o texto escrito, visualizada especialmente pela noção de "biografema". Desenvolvida pelo teórico guei Roland Barthes (1990), tal noção abarca um sujeito diferente daquele de constituição totalizante e linear, que costumava protagonizar biografias consagradas, consistindo, ao contrário, de modo "[...] disperso, um pouco como as cinzas que se atiram ao vento após a morte [...]" (BARTHES, 1990, p. 12). Cintila como possibilidade de captarmos, nesses traços fragmentados, a multiplicidade do ser cuja vivência, na narrativa, demonstra sinais da multiplicidade da qual é feita a vida mesma.

Ao entendermos a totalidade de uma vida como incapaz de ser atingida por construções narrativas, o biografema não elimina nem estigmatiza a hipótese de o sujeito

${ }^{3}$ Música "Proibido o carnaval", lançada em 2019. 
produtor do discurso recorrer à imaginação para, inclusive, preencher os vazios sobre acontecimentos que não pode acessar por meio de fontes e rastros históricos. Nessa linha de raciocínio, o conceito não resulta em uma técnica que busque expor verdades fugidias, mas se converte em ferramenta para uma crítica literária que visibilize certas temáticas, a exemplo da violência, da repressão e da resistência às variadas formas de opressão. Assim, permite proceder a desvios em relação ao cânone literário e às hierarquizações da história oficial.

No presente entendimento, seguimos a proposição de Leonor Arfuch (2010, p. 223), segundo a qual "[...] poderia se afirmar que toda literatura-escrita é autobiográfica na medida em que participa desse plano concreto, não por aglutinar convencionalmente um conjunto de tropos, mas por compartilhar, mesmo sem confessar, medos, paixões, obsessões, fantasias". Dessa forma, identificamos a relação do autor com a homossexualidade, na irrupção dos temas que ganham corpo em seu texto dramatúrgico (não trabalhamos com o espetáculo em si), na medida em que podemos perceber aspectos identificáveis nas biografias de outros gueis (seus medos, paixões, obsessões e fantasias).

É o que, de certa maneira, elabora Didier Eribon (2000), em Reflexiones sobre la cuestión guei, ao transbordar o relato pessoal e possibilitar o reconhecimento de pessoas com histórias, vivências e experiências semelhantes, que são objetos de olhares diversos e têm suas palavras tomadas por outros. Assim, empoderar-se viria a ser, dentre outras coisas, atribuir-se do direito de responder a perguntas e a demandas próprias, bem como de produzir discursos e agenciamentos. autor ressalta a importância de "falar por si mesmo", o que se torna fundamental na perspectiva em que o "nós por nós" se apresenta no sentido de uma apropriação do discurso do poder de fala, como parte de um esforço para construir alternativas às forças opressivas:

Temos que renunciar à utopia de uma sociedade ideal em que os homossexuais não fossem condenados ao ostracismo ou à ofensa... mas podemos, por um lado, empreender com sucesso batalhas pela igualdade dos direitos e, por outro lado, esforçarmo-nos para escapar, em certa medida, das forças opressivas. A resistência não é a projeção de nós mesmos em um futuro hipotético e incerto, mas uma manifestação, possível hoje, de proceder a um desvio em relação à norma (ERIBON, 2000, p. 77, tradução nossa $)^{5}$.

\footnotetext{
5 Texto-fonte: "Tenemos que renunciar a la utopía de una sociedad ideal en la que los homosexuales no fuesen condenados al ostracismo o insultados... pero podemos, por una parte, emprender con éxito batallas por la igualdad de los derechos y, por otra, esforzarnos en escapar, en cierta medida, a las fuerzas opresivas. La resistencia no es la proyección de de nosotros mismos en un futuro hipotético e incierto, sino la manifestación, posible hoy, de una desviación en relación con la norma" (ERIBON, 2000, p. 77).
} 
Não havendo exterioridade social, nem política ou cultural, precisamos situar-nos ao lado da contra-hegemonia, inventando outras formas de vida, de identidade e outros modelos sociais, não apenas ao exercermos subversão, mas também ao produzirmos novas respostas às questões atuais para agenciar a subjetivação de sujeitos oprimidos e subalternizados. Nesse sentido, concordamos com o filósofo francês Michel Foucault (2010), ao afirmar, em seus estudos, que parece desnecessário questionar o porquê de os seres humanos se jogarem à resistência contra um sistema de poderes e normas caracterizado por incluir uns e segregar outros: "E porque o homem que se rebela é em definitivo sem explicação, é preciso um dilaceramento que interrompa o fio da história e suas longas cadeias de razões, para que um homem possa 'realmente' preferir o risco da morte à certeza de ter de obedecer" (p. 77).

A questão parece latente no enfrentamento à "ditadura hétero-militar brasileira", assim denominada por Renan Honório Quinalha (2017) em sua tese de doutorado Contra a moral e os bons costumes: a política sexual da ditadura brasileira (1964-1988), na qual considera que a perseguição às homossexualidades foi programática, e parte da política de Estado, registrando variadas formas de violência à população LGBTQI+. Daí que representações artístico-literárias situadas no contexto sociopolítico referido sejam capazes de expor a complexidade de personagens homoeroticamente inclinadas e como os efeitos danosos do regime atingiram os movimentos homossexuais que, à época, se assinalavam pela demarcação identitária e pela reivindicação de direitos civis.

Na mesma linha de agenciamento teórico, ao pensar em processos de ruptura com a história oficial e de rebelião contra o regime masculinista no qual se insere o cânone literário, Antônio de Pádua Dias da Silva (2009) pensa que "[...] a produção literária brasileira de temática guei, por atender a critérios já postulados por aspectos teóricos e/ou críticos da literatura, não se configura em mera plataforma sexual" (p. 96). Ocorre que, para os sujeitos heterossexuais, suas expressões apresentam-se como comuns e consolidadas, de modo a não necessitarem de um termo que lhes dê destaque, ou de uma discussão prévia sobre sua fundamentação, pois se tornam simplesmente o sinônimo do status quo e se inserem na lógica da normalidade, do naturalizado:

No âmbito artístico-representacional, a noção de desejo guei imbui-se de alto valor para os sujeitos homoafetivos, porque ela referenda uma prática já consolidada entre os sujeitos heterossexuais, todavia sem um nome específico, uma vez que, na cultura ocidental falocêntrica, o androcentrismo é o modelo, o padrão, a norma, visão bastante discutida por Michel Foucault (SILVA, 2009, p. 99). 
Sobre a definição do que seria uma literatura guei/homoerótica, o autor inscreve-se na perspectiva de Eribon, pois se refere a representações que envolvam sujeitos homoeroticamente inclinados e suas táticas para promoção de visibilidade:

\begin{abstract}
Todo e qualquer texto literário ou de ficção que represente prioritariamente (não exclusivamente) questões referentes à cultura guei, seja através de personagens (centrais), de narradores, de falas, de discursos, de práticas discursivas, de alusões ao submundo guei, que exponham ou não conflitos envolvendo os gueis e os não gueis, numa demonstração de que a ficção vislumbra uma sociedade tolerante à diversidade sexual, ao mesmo tempo em que a mimetiza como homofóbica (SILVA, 2009, p. 102, grifos do autor).
\end{abstract}

Uma escrita homoerótica não se encerra nesse universo, mas pode se converter em espaço para tratar a diversidade sexual e de gênero como mais uma faceta da experiência humana, capaz de desconstruir estereótipos já naturalizados e que vez ou outra aparecem, inclusive em perspectivas supostamente engajadas, portanto, passíveis de apontamentos que as rasurem ou, pelo menos, as levem à autocrítica. Assim, distintas representações de pessoas de identidade e orientação sexual não prescritas como "normais" podem evadir-se de locais onde sejam apenas faladas/narradas por outros, a fim de produzirem discursos e agenciarem formas de discordância, como lembra Raphaella Silva Pereira de Oliveira (2011):

O corpo e a sexualidade são espaços disciplinados, e controlados. São marcados e marcadores de diferenças na sociedade. São também construídos discursivamente, normatizados por ele. As práticas homossexual, bissexual, lésbica são tidas como desviantes. Escrever sobre essas vivências, amores e desejos não passa apenas por busca de visibilidade e de escuta, mas também por tática de sobrevivência (p. 58).

Da mesma forma, Mário César Lugarinho (2003) observa exemplos de momentos históricos durante os quais a reivindicação da "naturalidade" da condição homossexual foi duramente reprimida, pelo Estado e pelo cânone. Para tanto, foram utilizadas proibições, interdições e o silenciamento de sujeitos comprometidos com uma estética de valorização da homossexualidade:

Deve-se levar em consideração que a reivindicação das ditas minorias não foram atendidas pacificamente pela História; há de se notar que toda reivindicação oriunda dos agrupamentos minoritários só pôde ter lugar como resposta à violência praticada pelas elites no seu esforço uniformizador (LUGARINHO, 2003, p. 136). 
Com efeito, parte das obras e sujeitos canonizados é erigida por questões pessoais, político-partidárias, religiosas, ideológicas, além de retroalimentada por outros fatores que interferem diretamente no incentivo à sua produção e recepção. Consequentemente, na determinação do público e do mercado aptos a consumirem tal produto/obra, tornando-se necessário reforçar: "[...] é possível, do ponto de vista estético e político, não inventar (no sentido do forjamento, do 'forçar a barra'), mas levantar, trazer à tona, descrever, analisar, historiar, classificar, criticar ou mesmo apenas exibir a literatura brasileira de temática guei" (SILVA, 2009, p. 104). Essa visão contrapõe-se a noções recorrentes no senso comum e propagadas em grande parte pela mídia hegemônica, contrastando situações como a descrita por Paulo Cesar Souza García (2013) ao discutir a crítica sobre a escrita de João Gilberto Noll:

\begin{abstract}
A palavra de ordem 'terapia de choque' [...] ocupa o lugar de punição para aqueles não sintonizados com a sociedade. É considerado 'viável' o tratamento dos desajustados, como ocorrera com Noll, com a homossexualidade, aplicando o recurso da disciplinização para quem entra em distúrbio. São recursos que se tornam precisos para domar o uso dos prazeres, cabendo à ciência a responsabilidade de nomear os homossexuais como perturbados, anormais e alienáveis para a ordem social e para um mundo produtivo. Visto esse sentido, é o olhar das margens que fomos obrigados a desenvolver, como assegura Trevisan (2004, p. 510). Um olhar sobre o qual se debruçam outras linguagens para nos tornar existentes num fórum crítico à cultura de choques, de modo a compor um mundo diferencial (p. 90, grifos do autor).
\end{abstract}

Assim, a literatura homoerótica possibilita encaminhar discussões sobre diferença, diversidade, subjetividade, cultura, saberes, mitos e epistemologias marcados por narrativas de vivências e experiências que diferem do modelo heterossexual tradicional. Entretanto, na ótica da perspectiva majoritariamente heteronormativa ${ }^{6}$, quando não homofóbica, da crítica literária brasileira, autores como Fernando Mello (1945-1997) são alvo de pouco interesse, conforme esclarecem Arivaldo Sacramento de Souza e Rosa Borges dos Santos (2012):

Embora tenha sido um dramaturgo em pleno vigor na década de 1970, há pouquíssimos trabalhos sobre sua dramaturgia, o que permite concluir de um considerável descaso com a memória do teatro brasileiro, ainda mais

${ }^{6}$ Segundo Lauren Berlant e Michael Warner (2002, p. 250): "Por heteronormatividade entendemos aquelas instituições, estruturas de compreensão e orientações práticas que não só fazem que a heterossexualidade pareça coerente - quer dizer, organizada como sexualidade - mas também privilegiada. Sua coerência é sempre provisória e seu privilégio pode adotar várias formas (que às vezes são contraditórias): passa desapercebida como linguagem básica sobre os aspectos sociais e pessoais, se percebe como um estado natural, também se projeta como um logro ideal ou moral". 
quando se trata de temas marginalizados como a homossexualidade na cena urbana carioca (p. 1571).

O seu drama Greta Garbo quem diria acabou no Irajá (MELLO, 1974)ㄱ, daqui para diante, chamado apenas de GG, alcançou sucesso nacional, mas é extremamente difícil conseguir informações sobre o escritor que, nascido em Recife, ainda jovem (com 23 anos) se projetava na cena autoral, ao produzir peças premiadas. Obtivemos as informações que constam neste trabalho por intermédio: a) da revista da Sociedade Brasileira de Autores Teatrais (SBAT), na qual foi publicado o texto (de 1974) com o qual trabalhamos; b) das pesquisas de Arivaldo Sacramento de Souza $(2010$; 2014) e desse autor em coautoria com Rosa Borges dos Santos (SACRAMENTO; SANTOS, 2011; 2012); c) dos e-mails trocados com a equipe do SBAT, no ano de 2016, quando fomos informados de que Fernando Mello faleceu no dia 28 de agosto de 1997 e a detentora dos direitos autorais era a sua irmã. No estudo aqui processado, porém, não buscamos traçar percursos biográficos, mas verificar como a obra literária em foco, embora engendre estereótipos, também pode apresentar resistências.

O texto dramático em análise foi escrito num momento de forte patrulhamento ideológico, promovido por uma doutrina militar (pretensamente) cristã e moralista:

[...] produzido numa época bastante conturbada em que as artes brasileiras passaram por ostensiva vigilância dos governos militares. Essa ditadura no Brasil centralizou, contundentemente, o poder no Estado de tal modo que construiu uma censura severa para os diversos campos da comunicação e das artes. Todo discurso produzido pelos jornais, revistas, programas de televisão, de rádio, teatro e cinema tinha de passar, antes, pela Divisão de Censura de Diversões Públicas (DCDP), onde técnicos de censura exaravam pareceres de liberação ou veto com base numa legislação (Decreto-Lei $n^{\circ} 1.077$, de 26 de janeiro de 1970) que operava com princípios etnocêntricos de civilidade, ética, moral e religiosidade cristã (SACRAMENTO; SANTOS, 2012, p. 1571, grifos dos autores).

Sacramento e Santos (2012) ainda ofertam outra informação obtida através da análise de pareceres dos censores do regime militar sobre o texto dramático estudado:

Em consulta ao Arquivo Nacional, na busca pelos pareceres da censura sobre o referido texto, soube-se que havia um fundo para a Divisão de

\footnotetext{
71974 é a data de publicação do texto na Revista da SBAT. Há uma versão submetida ao Serviço de Censura e Diversões Públicas (SCDP) em 1971 pela Pichin Plá produções, da atriz e produtora falecida em 2009, Iris Doraplá, conhecida como Pitchim Plá. A edição submetida ao SCDP era uma cópia xerocada de uma versão datilografada, datada de 23/25 de julho 1970 (SACRAMENTO; SANTOS, 2012).
} 
Censura de Diversões Públicas, no qual constavam 645 páginas de diferentes tipos documentais relacionados exclusivamente a Greta Garbo: pareceres, fichas de acompanhamento, autorização para representação da SBAT, scripts (testemunhos mimeografados a álcool, à óleo, impressos), relatórios de ensaio geral, certificados de censura, protocolos de acompanhamento, radiogramas, enfim (p.1572).

Isso não acarretou no impedimento da sua realização e, embora os cortes da censura fossem pequenos em tamanho físico (um pequeno risco em caneta vermelha), trata-se "[...] quase sempre das cenas em que a relação homoafetiva se dá com maior intensidade" (SACRAMENTO, 2010, p. 1). Portanto, constituem-se como um grande golpe frontal no sentido dramatúrgico do texto, como forma de tentar impedir o aparecimento de imagens positivas do mundo homoerótico na arte, golpeando um dos seus pontos altos - o quadro de uma relação amorosa entre dois homens no período da ditadura militar -

Greta Garbo não escapou ilesa de todo esse processo, principalmente, porque nela lemos um romance entre Pedro, ou melhor, 'Greta Garbo dos pobres', enfermeiro homossexual de quarenta e poucos anos, e Renato, jovem do interior que vem em busca do sonho de ser médico na cidade grande: uma relação homoafetiva (SACRAMENTO; SANTOS, 2012, p. 1571).

Em distintos momentos, Sacramento e Santos (2012) apontam a opinião sobre o drama em análise, por parte dos censores do regime, os quais julgaram que, embora reapresentasse a temática homossexual, não incentivava nem a prática homoerótica, nem outros assuntos "degradados", construídos na dinâmica textual. Talvez porque suas três personagens mais destacadas, ainda que não aceitas pelo status quo, tampouco se distanciariam do foco central do discurso burguês: casamento, família, estabelecimento econômico e ordem heterossexual. Convém lembrar que, em geral,

\begin{abstract}
No campo literário, segundo Alexandrian (1994), os homossexuais, invertidos, sodomitas, onanistas ou pederastas sempre foram representados, mesmo quando essa representação era pintada com as tintas do humor e da caricatura. A estereotipia era a marca central das personagens, reiterando-se, assim, a imagem que foi perpetuada, até meados do século XX [...] (SILVA, 2016, p. 80).
\end{abstract}

A narrativa de GG (MELLO, 1974) começa como Mellodrama, passa pela comédia, desemboca na crueldade e na amargura da relação entre personagens marginalizadas: Mary, 
prostituta com aspirações de "boa moça"; Renato, jovem do interior do estado do Rio de Janeiro, que sonha em ser médico e fazer dinheiro na capital; Pedro, enfermeiro guei que se empenha em manter uma vida conjugal com esse rapaz e se imagina a diva do cinema norteamericano Greta Garbo. Essas figuras simples entram no "palco" da trama, espaço em que vale a lei do mais forte, vencem aqueles que conseguirem tirar mais proveito dos menos "experientes". Assim como pessoas da vida real, convivem com mazelas sociais e, se em alguns momentos, reproduzem opressões e praticam explorações; em outros, rebelam-se contra ambas. A linguagem da qual se valem, quase sempre chula, violenta e debochada, mostra-se na voz do guei afeminado quando menciona uma travesti, personagem secundária na peça:

PEDRO - A Daniela me paga. Juro que me paga. Vou fazer picadinho de bicha e levar pros gatos do passeio.

PEDRO - Você já viu alguém colocar uma banana de dinamite no ouvido de alguém? É o que eu vou fazer com uma bruxa da Daniela (MELLO, 1974, p. 50).

O protagonista homossexual é representado predominantemente como alguém problemático e afetado, capaz de arrancar risadas com seu comportamento caricato:

PEDRO - põe essa mulher pra fora! Eu dou um escândalo, eu fico louca, eu tiro a roupa, eu subo pelas paredes.

[...]

PEDRO - Vai embora, mulher. Eu rodo a minha baiana, eu dou um histérico, eu fico louca varrida, eu me estraçalho toda (MELLO, 1974, p. 62)

Em trechos que podem soar como reprodutores da regulação heteronormativa, no entanto, irrompem posições de protesto, razão pela qual julgamos produtivo identificar posturas mais ou menos engajadas, no sentido estético, e politicamente comprometidas. A investigação desses lugares movediços permite-nos efetivar paralelos com a história, levando em conta, do mesmo modo, a potência vivencial da escrita biográfica. Falamos de experiências que moldam vidas: seja Fernando Mello e outros gueis da cena literária e dramatúrgica; sejam os sujeitos que guardem semelhanças em suas vivências com as personagens homossexuais do texto.

Ao nos propormos a abordá-las por intermédio de biografemas, preocupamo-nos com um estado de coisas ainda presente em nossa sociedade: o funcionamento da heteronormatividade, a ditar atitudes e pensamentos do ser humano, suas formas de perceber o outro, amar e se relacionar, condenando as que diferem das concepções de gênero e 
identidade consideradas como padrão. De tal maneira, o texto em estudo permite delinear um biografema do autor flâneur underground, ao qual podemos associar também os escritores gueis brasileiros Glauco Mattoso, Herbert Daniel e Roberto Piva, no sentido de que suas obras contemplam a errância pelas ruas, o vagar que reverbera em imagens de lugares marginais ou contraculturais.

Essa incidência biografemática se instala a partir do momento em que o jovem dramaturgo mostra familiaridade com temas e problemáticas marcados por espaços sociais com foco representativo negativo: o interior, a periferia, geografias underground, boates e esquinas da Cinelândia. Trata-se de locais marginalizados, permeados por "viados", putas ladras e travestis, possibilitando observar um conhecedor de territorialidades percorridas por existências marginais. A afirmação das suas práticas reivindica veiculação para suas expressões culturais e, ainda que de forma esteriotipada, se torna mais um passo dado para visibilizar representações teatrais homoeróticas fortemente censuradas na década de 1970.

A influência da diva Greta Garbo para a construção da identidade homoerótica de Pedro; sua identificação com a estrela hollywoodiana entre o glamour e o fracasso - "Será que Greta garbo teve uma vida tão enrolada? Se teve, coitada dela, coitadinha?" (MELLO, 1974, p. 62) - assinalam toda uma performatividade, estendida desde a decoração da casa ("o barroquismo da cafonice") até aos trejeitos "divísticos" da sua personalidade, que marcam o biografema da divice:

\begin{abstract}
Pedro - Eu explico. O negócio é o seguinte. Eu apenas quero que o lindo mancebo feche os olhos e diga que eu sou Greta Garbo. Se quiser pensar em outra, pode, mas tem que me chamar de Greta Garbo. Depois, eu te dou o dinheiro e você some, VAI PRO INFERNO!

Pedro: Filho, uma informação! A Cinelândia é um lugar onde várias pessoas se encontram, entende? Pessoas de tipos diversos, de vários times, entende? De um lado os narigudos, do outro, nós, mulheres (MELLO, 1974, p. 48).
\end{abstract}

O texto assinala-se por uma atmosfera de desconfiança, pois as personagens tentam, de alguma forma, tirar proveito uma da outra, enquanto defendem de algum modo o status quo. Em vários sentidos, associam-se a uma visão tradicionalista, coadunada com o regime militar, embora estejam todas (um pobre diabo vindo do interior, a prostituta e a "bicha" velha) às margens do sistema. Um dos seus pontos fortes é o momento no qual problematiza a condição marginalizada das travestis e homossexuais afeminadas - mestiças, negras, periféricas -, comumente marcadas por uma infância problemática, que as leva às esquinas e à prostituição. Rejeitadas pelo lar e pelo Estado, essas personagens auxiliam a configurar o 
biografema da expulsão de casa, recorrente nas vidas desviadas e na literatura que as representa:

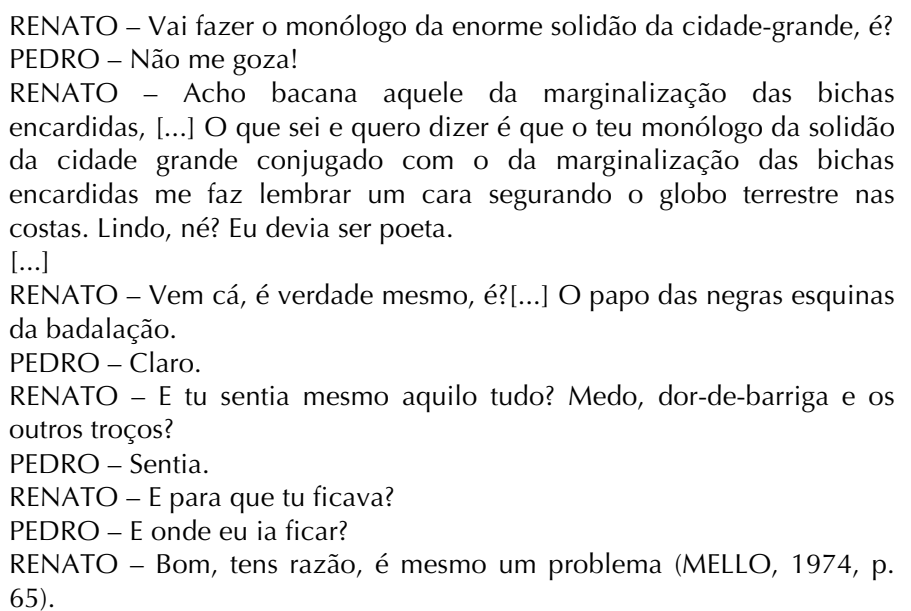

Outros vestígios de homofobia, racismo e preconceito de classe ocorrem quando esse rapaz se nega à investida sexual de Pedro, permitindo-nos identificar o biografema da abjeção $^{8}$ : "RENATO: - Sebastiana tá querendo o menino aqui, NE? Mas não vai ter, Sebastiana Pançuda, não vai ter. O menino gosta mesmo é de mulher. Mulher loura, de preferência. É, é... É, você é preta, Sebastiana Pançuda" (MELLO, 1974, p.53); ao que Pedro responde em protesto "Eu não sou preta, RENATO: - Encardida então." (MELLO, 1974, p. 53).

Essa questão não parece ter ganhado relevância nos palcos, já que, nas primeiras encenações realizadas nas principais capitais brasileiras, entre 1973 e 1975, o papel de Pedro ganhou vida nas atuações de Raul Cortez, e na sequência, Nestor Montemar. No esquema de "pirâmide racial" da ideologia de branqueamento presente em nosso país, o segundo ator poderia ser considerado "mestiço", "encardido" (como frisa Renato), não branco, enquanto o primeiro era branco. Renato inferioriza o protagonista: a) pela forma física - "gorda, pançuda" -, diferente daquela cultuada pela norma; b) pelo respectivo menosprezo à afeminação e aos traços étnicos-raciais daquele, ao afirmar sua preferência por "mulher" e loura", em contraste

\footnotetext{
${ }^{8}$ Sobre o conceito de "abjeção", embora Judith Butler enfoque nos sujeitos não humanizados pelos discursos do sexo e da heteronormatividade, na entrevista concedida a Baukje Prins e Irene Costera Meijer (2002), a teórica fornece exemplo didático de como a mídia ocidental trata refugiados libaneses e turcos quando são mortos ou mutilados: são corpos e vidas que não ganham especificidade, não têm as mesmas histórias familiares e complexas dos europeus que morreram ou cometeram crimes. Dessa forma "[...] recebemos uma produção diferenciada, ou uma materialização diferenciada, do humano. E também recebemos, acho eu, uma produção do abjeto. Então, não é que o impensável, que aquilo que não pode ser vivido ou compreendido não tenha uma vida discursiva; ele certamente a tem. Mas ele vive dentro do discurso como a figura absolutamente não questionada, a figura indistinta e sem conteúdo de algo que ainda não se tornou real" (p. 162).
} 
à "preta"; c) pelo apelido que Ihe dá ("Sebastiana", associado à pobreza), ao sonegar qualquer possível glamour relacionado à autoprojeção da personagem central em Greta Garbo.

Os insultos recebidos por Pedro - "preta" e "encardida" - permitem conjeturar sua prefiguração como não branco. Assim, foge aos padrões de Renato, o qual afirma gostar de mulher, loira, branca, magra e, além de tudo, que não se encontre em situação de vulnerabilidade social:

\begin{abstract}
Ao afirmar isso, ele se torna um agente operador de um discurso que acredita na inferioridade estética pela cor da pele e pelo gênero, mas também há uma questão de classe, já que é de conhecimento público apelidar homossexuais com nomes antigos e/ou mais clássicos para sinalizar um possível pertencimento a uma classe social menos abastada (SACRAMENTO, 2014, p. 276).
\end{abstract}

Pedro situa-se entre o glamour "garboriano" e sua condição étnica, sexual e social, sua complexidade efetiva-se nas formas de opressão às quais se submete: patriarcado, sistema de classes, heterossexismo e racismo. Portanto, não poderiámos fazer uma análise pertinente da personagem, sem entender como se associa às margens sociais, de modo que uma mirada interseccional ${ }^{9}$ a identifica em múltipla marginalização, da qual não consegue fugir mesmo após os 25 anos de trabalho como enfermeiro, que lhe proporcionaram certa estabilidade econômica.

Por outro lado, quando expressa seu discurso plano, Mary sente nojo ao descobrir a relação amorosa mantida entre Renato e Pedro que, por sua vez, escarniza a condição dela, de trabalhadora sexual. Enquanto oprimidos se discriminam mutuamente, a prostituta reafirma o biografema da bicha maldita ${ }^{10}$ :

MARY - Eu to manjando tudo, ouviu? Eu já tinha manjado desde o início. Eu sou macaca velha, escolada. Conheço um veado longe.

\footnotetext{
${ }^{9}$ Interseccionalidade é uma ferramenta teórica e metodológica cunhada pela ativista dos direitos civis Kimberlé Williams Crenshaw, no trabalho Mapeando as margens: interseccionalidade, políticas de identidade e violência contra mulheres não-brancas, de 1991, e desenvolvido por estudos do feminismo negro. Trata-se do enfoque a diferentes formas de dominação e discriminação, como o patriarcado, o capitalismo, o racismo e o heterossexismo, que implicam em diferentes formas de opressão, as quais, imbricadas entre si, colocam os sujeitos em maior ou menor nível de marginalização e acesso a direitos civis.

10 Tales Santos Pereira (2016), durante a III Jornada de Literatura, História e (Auto)Biografia, realizada no IFBA, campus Salvador (BA), apresentou a comunicação oral Ave divas, cheias de glamour, quando expôs a ideia de "biografema da bicha maldita". Essa noção representa um sujeito, tanto existente quanto representado em diversas plataformas artísticas e literárias, que reage à sociedade heterocentrista por meio de "um deboche encarnado" "[...] com o peso e a graça do verbo ofídico e impiedoso, nada escapa da sua satírica aguda". Considerando que muitos a odeiam, a bicha maldita desenvolve atitudes defensivas e armadas frente ao mundo, contra o qual não apenas protesta, mas também promove formas de opressão.
} 
PEDRO - Já que que você constatou o óbvio, meu bem, saiba: ele é o meu marido. E você, a outra.

MARY - Renato, seu safado. Safados, os dois!

[...]

MARY (Empurra-o [renato]) - Nunca mais fale comigo, seu senvergonha, seu sujo, seu porco, seu... seu... seu marido de bicha!

$[\ldots]$

PEDRO - Ele não vai perder muita coisa mesmo, Uma piranha suadora, xexelenta, mentirosa, oxigenada. Vai pro bordel, filhinha Titia tá esperando.

MARY - Eu vou mesmo, Eu não sei o que diabo ainda estou fazendo aqui. Cocôsauro! Bichona!

[...]

MARY - Pederástico. Bichona (T) Maridinho e mulherzinha. Vão às putas que os pariu! (sai) (MELLO, 1974, p. 62).

Já em Renato, encontramos diferentes posturas: no ínicio da sua aparição, desconversava a orientação de Pedro; no desenvolvimento, mostra-se um gigolô aproveitador; nos momentos finais, inclina-se à flexibilidade, permitindo-se ao desejo. Ilustrando outras formas de experienciar a sexualidade, a personagem em destaque questiona a própria caracterização do guei enquanto identidade praticamente fixada, como uma caixinha que presume um tipo de ser humano. O desenrolar do seu envolvimento com o enfermeiro questiona a imagem cristilizada pelo senso comum, pelas tradicionais aparições dos gueis na arte e nas mídias, ao disseminarem a ideia de que a sexualidade defina a personalidade e comportamentos específicos:

RENATO - [...] O garotinho aqui quer curtir sim a sua amada bicha velha. O que? Pura curtição. O garotinho aqui ama a sua amada velhota. PEDRO - Faz favor de não me chamar de velhota.

RENATO - Saco! Eu tô falando que te amo, droga.

[...]

MARY - Vim saber se aconteceu alguma coisa, te ver.

RENATO - E eis que você me encontra solidamente convicto da pederastia ativa e ligeiramente inclinado a provar da outra.

Mary - RENATO!?

RENATO (Rindo) - E não vem o monólogo do nunca-pensei, hem?

PEDRO - Ave Maria.

MARY (A PEDRO) - O que foi que você fez com ele, hem?

PEDRO - Eu, nada.

RENATO - Entupiu a minha cuca. Quer dizer, porque eu pedi e implorei.

Eu até peguei.

PEDRO - Renato!

RENATO - Não tem problema cara, Foi ela quem me iniciou (MELLO, 1974, p. 64-67-68).

Enraizadas na moral da época, todas as personagens possuem sonhos e ideais de ascenção social. A peça opera um tom conformista, ilustrado pela decadência de Pedro e pelo último ato, quando Renato volta para o interior, a prostituta foge da polícia, o amor guei, 
como em tantas outras obras, não se realiza: "O título Greta Garbo, quem diria, acabou no Irajá em si vaticina o final da peça: o insucesso amoroso e a solidão do enfermeiro Pedro/Garbo." (SACRAMENTO, 2010). Assim, o biografema do amor guei não concretizado converte-se em desfecho de aparência perfeita para agradar à censura, pois na conclusão de um dos pareceres, o texto "[...] não contém nenhuma incitação à prática dos fatos ou das situações ali mostradas nem se apresenta de maneira chocante [...]" (SACRAMENTO, 2011, p. 8).

A resistência ocorre em forma de deslize, mostrando sensibilidade e astúcia por parte do autor. Detrás de um aparente acirramento da briga entre a mulher e "bicha" pelo homem amado, pode estar uma desesperada busca pela felicidade, uma crítica à solidão dos grandes centros, à carência de afeto e solidariedade, talvez indisponíveis para pessoas como Pedro, relegado às esquinas e à canalhice:

PEDRO - Você perdeu, meu anjo. Ele é meu. E não vem com moral, tá? Eu dou um bananão prá tua moral. Ninguém pensou em quando eu tava perdendo. Não é uma guerra? Não vale tudo? Tá bom, eu topo tudo. Qual é a próxima canalhice que eu tenho que fazer pra ser feliz? Fala Renato eu faço. Enchi o saco de perder, enchi o saco de ser tato badalando nas esquinas, ENCHI O SACO! (MELLO, 1974, p. 67).

Em vez de constituir esteriótipos, essa cena engedra críticas à frieza da sociedade para com as vidas de gueis, travestis e dissidentes sexuais, que apresentam como aspecto comum a saída do seio familiar. Muitas vezes, a mudança para as grandes capitais, para recorrerem ao anonimato das multidões, resulta em alternativa contra injúrias e violências, às quais parecem mais expostos em cidades pequenas. A identificação com semelhantes e a convivência gregária igualmente contribuem para delinear o biografema do "viado" metropolitano, como é o caso de Pedro.

Por outro lado, a metrópole em que Renato se livra de alguns aspectos reprimidos em sua sexualidade assiste ao seu esforço pela adequação, tentando aproximar-se cada vez mais das falas locais, em busca de um status a ostentar com seus conterrâneos do interior:

RENATO - O meu sotaque carioca está bom? O pessoal lá em Campos se amarra no sotaque carioca.

PEDRO - O teu sotaque está ótimo (MELLO, 1974, p. 68).

Na mesma passagem, outro aspecto que exibe a engenhosidade do autor é a forma por meio da qual a relação entre Pedro e Renato começa de forma tensa, marcada por um 
comportamento pretensamente inocente e melindroso por parte desse, em busca de compensação financeira, assim como pelo interesse do enfermeiro em tê-lo como seu objeto. No desenvolvimento do enredo, o rapaz busca extrair dinheiro a fim de sustentar o seu vício em álcool e, por fim, assume que sentia prazer com o protagonista. Delineia-se uma espécie de amizade e respeito, caminhando para o encerramento de tom cada vez mais amoroso entre os dois, que se despedem com um beijo, em trecho cuja encenação fora cortada pelo parecer da censura:

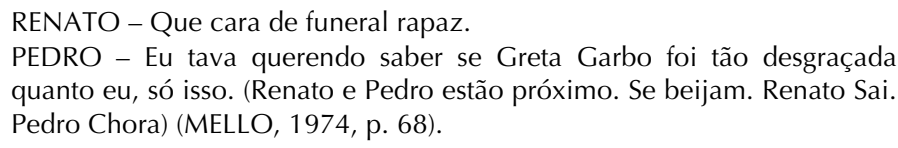

O autor realiza fissuras no discurso heteronormativo, ao reivindicar as sexualidades desviantes da norma essencializada e naturalizada, como no diálogo seguinte, quando Pedro pergunta o que se fala sobre os homossexuais no interior do estado do Rio de Janeiro, onde Renato mora:

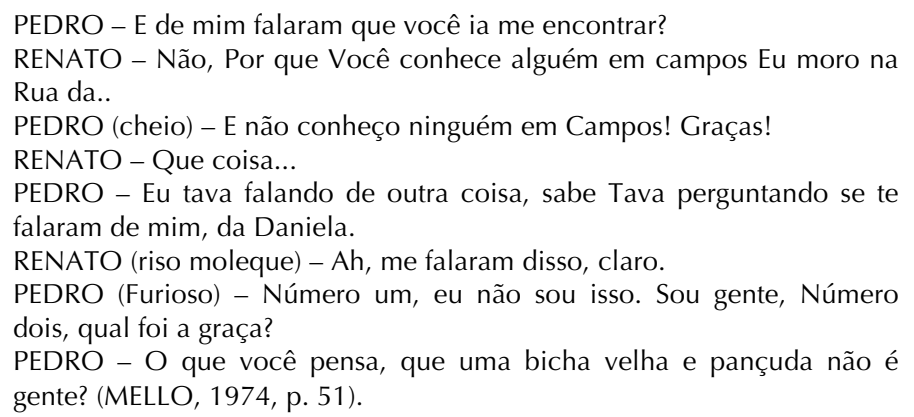

Mediada pelo conceito de biografema, nossa leitura dessa temática pouco veiculada nos estudos literários da forma como se apresenta, ao tempo de sua escrita e encenação, demonstra a competência de Fernando Mello para driblar os mecanismos censórios. Importa frisar que, em fevereiro de 1970, foi o primeiro autor no teatro nacional a se tornar alvo do recente Decreto-lei 1.077, que estabelecia censura prévia, por causa da peça Quantos olhos tinha o teu último casinho?. No ano seguinte, teria seu premiado drama A pequena tragédia de Vera Marai de Jesus, a condessa da lapa, também interditado pelo regime.

O autor vale-se de ambiguidades textuais que, ao esquivá-lo dos censores, não subtraem as complexidades de suas estórias dramáticas. Por um lado, expõe ex-centridades 
das personagens visando provocar o riso, como o trabalho sexual exercido por Mary, os estereótipos da homossexualidade, relacionados a Pedro, e a condição de gigolô vivida por Renato. Por outro lado, chama atenção às adversidades cotidianas de um homem guei quarentão e com maneiras femininas; à precariedade do trabalho sexual no Brasil; à luta pela sobrevivência nos centros urbanos. Em meio a diálogos ácidos e cenas, algumas vezes, caricaturais, imiscui-se a criminalização dirigida a sujeitos considerados "pervertidos" e "desviados" pela política de Estado hétero-militar que, ao promover a criação de "inimigos internos", se valeu "[...] de contornos não apenas políticos de acordo com a doutrina da Segurança Nacional, mas também morais, ao associar a homosssexualidade a uma forma de degeneração e de corrupção da juventude" (QUINALHA, 2017, p. 23).

Essa situação poderia passar desapercebida caso a crítica a GG (MELLO, 1974) se ativesse à representação humilhante, caricata e reprimida da homossexualidade ou a trechos nos quais situações tensas com pessoas em zona de risco parecem minimizar-se quando pintadas de forma engraçada. Como alerta Henrique Oscar (1974),

\footnotetext{
[...] não é uma procura de sensacionalismo, um recurso a efeitos fáceis de pitoresco, como uma impressão superficial poderia sugerir. As características das personagens e do enredo não the tiram uma universalidade e autenticidade que permaneceriam se transpostas para situações diferentes. Trata-se de um corte na vida de três seres marginalizados - até que ponto por suas próprias condutas ou pela sociedade não há espaço para discutir aqui - como deixa clara uma leitura em profundidade do texto (p. 44).
}

Uma visada mais atenta à relação homoerótica representada na peça analisada faz notar que, em alguns momentos, ultrapassa imagens de poder cristalizadas na literatura, nas artes e nas mídias, tais como o domínio do ativo sobre o passivo e, numa relação financeirizada, a superoridade daquele que detém o poder aquisitivo. Nesse aspecto, oferece perspectivas contrapostas a estereótipos binários, a exemplo de "bicha" x bofe; "maricona" x michê, uma vez que Pedro deixa de ser simplesmente quem paga por sexo e Renato transcende a condição de mero explorador.

Ao final, revela-se uma peculiar forma de amor na inclinação do jovem interiorano à homossexualidade, inclusive, à condição "passiva". Sabendo dos cortes no beijo e em passagens de maior afeto, esse movimento de flexibilização sexual tem seu sentido apagado do texto e das encenações previstas. A censura, do mesmo modo que uma parcela média dos brasileiros, "[...] confundia homossexualidade masculina com efeminação [...], subdividindo os homens que se envolvem em atividade homoeróticas em duas categorias - o homem (o 
homem 'verdadeiro') e o 'bicha'"(GREEN, 2000, p. 27, grifos do autor); o ativo e o passivo. Nesse modelo, o não efeminado, ativo, é entendido como heterossexual e viril e o segundo, como guei e frágil.

A volta de Renato para a cidade natal constitui um dilema: deve-se ao fracasso da utopia de prosperidade, ao vício em álcool e drogas ou ao medo de aceitar a sexualidade experienciada na cidade grande? Talvez Fernando Mello encontrasse, no retorno à casa, uma saída para aproximar a discussão empreendida no seu drama às expectativas dos censores, interditando a concretização do relacionamento amoroso, que provavelmente seria vetado por apologia expressa à homossexualidade. Não seria demais lembrar que os censores avaliavam os textos, pensando nas futuras exibições, e procuravam acompanhar os ensaios, a fim de checar tanto se as encenações contemplariam os cortes quanto as possibilidades de serem reintroduzidos no momento do espetáculo.

A "homossexualidade" de Pedro, na leitura dos censores, é invisibilizada, pois do ponto de vista de uma "política da identidade", poderíamos afirmar que Renato se torna guei ou bissexual. Do ponto de vista de teorias que rejeitam uma identidade sólida, ele poderia ser alguém que abriu mão de condutas e papéis sociais rígidos, ao experimentar aquilo que é proibido nas sociedades ocidentais cristianizadas: amar e se relacionar sexualmente com outro homem. Já prevista no texto, essa faceta ressignifica o seu encerramento, que não pode ser observado apenas pelo ponto de vista de uma sexualidade "reprimida", mas também a partir da produção de sentidos, pois como afirma Butler (2003), seguindo raciocínio de Foucault:

\footnotetext{
O poder, ao invés da lei, abrange tanto as funções ou relações diferenciais jurídicas (proibitivas e reguladoras) como as produtivas (ininten- cionalmente generativas). Consequentemente, a sexualidade que emerge na matriz das relações de poder não é uma simples duplicação ou cópia da lei ela mesma, uma repetição uniforme de uma economia mas- culinista da identidade. As produções se desviam de seus propósitos originais e mobilizam inadvertidamente possibilidades de 'sujeitos' que não apenas ultrapassam os limites da inteligibilidade cultural como efetivamente expandem as fronteiras do que é de fato culturalmente inteligível (p. 54).
}

Para tal compreensão, é importante ressaltar leituras descoladas das visões que condenaram a peça, por entenderem que: a) engendra mera reprodução de valores hegemônicos; b) promove estereótipos negativos das personagens marginalizadas. Isso seria injusto se observarmos o contexto de vigililância política e moral, assim como a postura crítica assumida por Fernando Mello, que já havia sofrido censura prévia em outros textos dramatúrgicos, e as relações de força que serão avaliadas a seguir. 
Arivaldo Sacramento (2014) analisa as disputas entre os setores da elite intelectual ligada a empresários da cultura e do entretenimento (que defendiam a encenação desse drama exitoso em público) e os adeptos do regime militar, favoráveis ao controle da subversão política, moral e sexual. Pareceres de "ilustrados" censores permitiram o incentivo financeiro à peça e que suas exibições não fossem canceladas, pois compreenderam que "Fernando Mello propunha uma redenção de Renato, ao se arrepender das relações com dois profissionais da decadência humana [Pedro e Mary]" (p. 329-330).

GG (MELLO, 1974) funcionaria então, na visão dos censores, como "[...] um recurso educativo, um exemplo para os jovens do que não fazer" (SACRAMENTO, 2014, p. 330). O efeito dessa visão moralista era garantido na montagem do espetáculo por meio da interdição aos momentos de carícias e afetos entre Pedro e Renato. Minorando efeitos críticos presentes no texto dramático, o regime militar e o mercado do entretenimento reorientaram o seu sentido, adaptando-o aos mecanismos ideológicos do poder regulador, para que ideológos do Estado e prósperos empresários saíssem lucrando com o sucesso nacional da produção. A versão editada com cortes reafirmava o caráter pedagógico dos valores culturais tidos como saúdaveis pela "ditadura hétero-militar" e legitimava uma verdadeira guerra, travada contra os subversivos da moral sexual e política por ela definida. Quando publicadas as edições acerca de tais engrenagens, ninguém diria que tantas Gretas e tantos Irajás, nos dias de hoje, fossem parar outra vez sob a mira ameaçadora das baionetas.

\section{Referências:}

ARFUCH, L. O espaço biográfico: dilemas da subjetividade contemporânea. Rio de Janeiro: EDUERJ, 2010.

BARTHES, R. Sade, Fourier, Loyola. São Paulo: Brasiliense, 1990.

BERLANT, L.; WARNER, M. Sexo em público. In: JIMÉNEZ, R. M. M. (ed.) Sexualidades transgressoras. Barcelona: Icaria, 2002. p. 229-257.

BUTLER, J. Problemas de gênero: feminismo e subversão da identidade. Rio de Janeiro: Civilização Brasileira, 2003.

DIDIER, E. Reflexiones sobre la cuestión guei. Barcelona: Belaterra, 2000.

FOUCAULT, M. Ética, sexualidade e política. Organização e seleção de textos por Manoel Barros da Motta. Trad. Elisa Monteiro, Inês Autran Dourado Barbosa. 2. ed. Rio de Janeiro: Forense Universitária, 2010.

GARCÍA, P. C. S. Literatura e representações do homoerotismo. Salvador: Editora da UNEB, 2013.

LUGARINHO, M. C. Literatura de Sodoma: o cânone literário e a identidade homossexual. Revista Gragoatá - corpos, erotismo e sexualidade, Niterói: UFF, v. 8, n. 14, p. 133-145, 2003. 
MELLO, F. Greta Garbo, Quem diria acabou no Irajá. Revista de teatro SBAT, Rio de Janeiro, n. 400, p. 42-69, jul./ago., 1974

OLIVEIRA, R. S. P. O lugar da escrita homoerótica: pensando a mostra generótica. In: Oliveira, A. L. et al. (Org.) Percursos da crítica cultural: artigos e ensaios de estudantes do Pós-crítica. Feira de Santana: UEFS Editora, 2011, p. 55-62.

OSCAR, H. Introdução a Fernando Mello e a Greta Garbo. Revista de teatro SBAT, Rio de Janeiro, n. 400, p. 42-45; 68-69, jul./ago., 1974.

MEIJER, I. C.; PRINS, B. Como os corpos se tornam matéria: entrevista com Judith Butler. Revista Estudos Feministas, Florianópolis, v. 10, n. 1, p. 155-167, Jan. 2002.

QUINALHA, R. H. Contra a moral e os bons costumes: A política sexual da ditadura brasileira (19641988). 2017. Tese (Doutorado em Relações Internacionais) - Instituto de Relações Internacionais, Universidade de São Paulo, São Paulo, 2017.

PEREIRA, T. S. Ave divas, cheias de glamour. (Apresentação de Trabalho/Comunicação). 2016. Texto no prelo.

SACRAMENTO, A. Nas tramas de Greta Garbo, quem diria, acabou no Irajá: crítica filológica e estudo de sexualidades. 2014. Tese (Doutorado em Literatura e Cultura), Universidade Federal da Bahia. Salvador, 2014.

SACRAMENTO, A. Rasuras de Greta Garbo: uma leitura de Greta Garbo, quem diria, acabou no Irajá. In: VI ENECULT - Encontro de Estudos Multidisciplinares em Cultura, 2010, Salvador. Anais do VI ENECULT Encontro de Estudos Multidisciplinares em Cultura. Salvador: FACOM, 2010. Disponível em: http://www.cult.ufba.br/wordpress/24484.pdf. Acesso em: 12 mar. 2019.

SACRAMENTO, A.; SANTOS, R. B. Arquivo Nacional, Departamento de Censura de Diversões Públicas: o caso Greta Garbo. In: XVI Congresso Nacional de Linguística e Filologia, 2012, Rio de Janeiro. Anais do XVI Congresso Nacional de Linguística e Filologia. Rio de Janeiro: EDUERJ, 2012. p. 1564-1578.

SACRAMENTO, A.; SANTOS, R. B. Os pareceres de Greta Garbo do Irajá. In: XII Congresso Internacional da ABRALIC: Centro, Centros; ética e estética, 2011, Curitiba. Anais do XII Congresso Internacional da ABRALIC: Centro, Centros; ética e estética. Curitiba: EDUFPR, 2011. p. 1-12.

SILVA, A. P. D. Literaturas de língua portuguesa e homoafetividade - $O$ aspecto político na ficção contemporânea. In: CAMARGO, F.; GARCÍA, P. C. (Org.) Homocultura e linguagens. Salvador: EDUNEB, 2016, p. 79-106.

SILVA, A. P. D. Uma visada sobre a construção discursiva em torno da literatura de temática homoerótica. In: ARANHA, S.; PEREIRA, T. \& ALMEIDA, M. L (Org.). Gêneros textuais e linguagem: diálogos abertos. João Pessoa: Universitária da UFPB, 2009, p. 95-107.

Recebido em 19/03/2019.

Aprovado em 24/04/2019. 